\title{
Konrad Pędziwiatr*
}

Uniwersytet Ekonomiczny w Krakowie

ORCID: 0000-0002-7547-6789

\section{TRANSFORMACJE POSTAW \\ WOBEC ARABÓW W SPOŁECZEŃSTWIE POLSKIM \\ Z PERSPEKTYWY CZŁONKÓW \\ SPOŁECZNOŚCI ARABSKIEJ I MUZUŁMAŃSKIEJ}

\begin{abstract}
Pomimo licznych badań postaw społeczeństwa polskiego wobec wyznawców islamu, w tym Arabów, lub badań tego, jak polskie media kształtują obraz muzułmanów i islamu, brakuje analiz ukazujących, jak te postawy i obrazy są odbierane przez grupę mniejszościową. Celem artykułu jest uzupełnienie tej luki i analiza postrzegania zmian postaw we współczesnym społeczeństwie polskim wobec Arabów z perspektywy członków krajowej społeczności arabskiej i muzułmańskiej. Ramę analityczną stanowią koncepcje socjologiczne problematyzujące grupowe poczucie obcości i swojskości w kontekście ludzkiej mobilności oraz w oderwaniu od tego kontekstu. W szczególności tekst ukazuje użyteczność koncepcji inności i obcości rozwijanej przez Ewę Nowicką w końcu latach dziewięćdziesiątych ubiegłego wieku do analizy następującej w ostatnich dwu dekadach transformacji postaw wobec Arabów i muzułmanów w społeczeństwie polskim.
\end{abstract}

Słowa kluczowe: islamofobia, muzułmanie, uprzedzenia, Arabowie, islam w Polsce, inność, obcość

\section{WSTĘP}

Społeczność arabska w Polsce stanowi najliczniejszą i jedną z najlepiej wyedukowanych i najzamożniejszych grup muzułmańskich w kraju (Kościelniak 2016: 390-391). Jej liderzy opisywani czasami w literaturze jako tzw. stara diaspora arabska (Switat 2017: 208-219) - najczęściej przybyli do kraju jeszcze przed upadkiem komunizmu i są dzisiaj naturalizowanymi Polakami nierozpoznawalnymi w statystykach migracyjnych. W ciągu niespełna dwu dekad społeczność ta stworzyła sieć organizacji w kraju (między innymi: Stowarzyszenie Studentów Muzułmańskich, Muzułmańskie Stowarzyszenie Kształcenia i Kultury oraz Ligę Muzułmańską w Rzeczpospolitej Polskiej) pełniących funkcje religijne, społeczne i kulturowe oraz pierwszy zbudowany od podstaw meczet w Warszawie w sąsiedztwie Dworca Zachodniego.

* Adres do korespondencji: Konrad Pędziwiatr, Centrum Zaawansowanych Badań Ludnościowych i Religijnych, Uniwersytet Ekonomiczny w Krakowie, ul. Rakowicka 27/B259,31-510 Kraków; e-mail: k.pedziwiatr@gmail.com. 
Te sukcesy organizacyjne - podobne do istotnej roli, jaką przedstawiciele wyżej wspomnianych organizacji odegrali w rewitalizacji religii wśród autochtonicznej społeczności muzułmańskiej w kraju (Warmińska 1999; Pędziwiatr 2011) - nie spotkały się jednak z uznaniem i przychylnością społeczeństwa przyjmującego. Jak pokazują badania CBOS-u na temat postrzegania przez Polaków innych narodów, od momentu gdy kategoria „Arabowie” została włączona do panelu pytań w 2002 roku, omawiana grupa notowała jedne z najwyższych wskaźników niechęci oraz najniższe wskaźniki sympatii. Dystans społeczny do Arabów w społeczeństwie polskim w świetle tych badań nieznacznie zmniejszył się na przełomie lat 2008-2012, czyli tuż przed wybuchem tzw. arabskiej wiosny i bezpośrednio po wybuchu rewolt w krajach Afryki Północnej i Bliskiego Wschodu, ale bardzo szybko powrócił do stanu sprzed tego okresu. Jedna z ostatnich edycji tego badania z lutego 2018 roku potwierdziła, że Arabowie to obok Romów grupa społeczna, do której Polacy deklarują najmniejszą sympatię (10\% dla Arabów i 12\% dla Romów) oraz największą niechęć (62\% dla Arabów i 59\% dla Romów) (CBOS 2018).

Inne badanie postrzegania cudzoziemców przez Polaków przeprowadzone w 2016 roku przez Ipsos na zlecenie Międzynarodowej Organizacji ds. Migracji wykazało, że Arabowie są postrzegani jako rzekomo „najbardziej odległa kulturowo grupa od Polaków” i jako taka darzona jest najmniejszym zaufaniem. Trzy czwarte Polaków według IPSOS nie zaakceptowałaby Araba jako członka rodziny (IOM 2016). Badania te potwierdzają również analizy badaczy z Centrum Badań nad Uprzedzeniami wskazujące między innymi, iż Polacy cechują się wysokim poziomem islamofobii (m.in. Stefaniak 2015; Skrodzka i Stefaniak 2017; Wiśniewski et al. 2017). Arabskość jest postrzegana we współczesnej Polsce przede wszystkim w kategoriach strachu przed „obcymi”, w dużej mierze wyobrażonymi i znanymi głównie z ekranów telewizorów i komputerów (CBOS 2015). Pozbawiona została swej wielowymiarowości, w świetle której była widziana jeszcze w latach osiemdziesiątych XX wieku i jawi się Polakom przede wszystkim w wymiarze religijnym oraz konfliktu cywilizacyjnego jako siła dążąca rzekomo do zdominowania „chrześcijańskiej Polski i Europy” (Pędziwiatr 2016, 2017). Potwierdzają to między innymi analizy CBOS-u, które pokazują, że w ciągu ośmiu lat (2006-2015) odnotowano 15-punktowy wzrost przekonania o nieuniknionym konflikcie międzykulturowym (CBOS 2015). Ważnym rysem krajowej islamofobii, czyli uogólnionych negatywnych postaw lub uczuć wobec islamu lub jego wiernych (Bleich 2011) jest przenoszenie ich w pierwszej kolejności na Arabów. Dzieje się tak, gdyż islam - mimo że jedynie co piąty jego wyznawca to Arab (Berkley Centre 2018) - postrzegany jest przez Polaków jako religia przede wszystkim arabska. W ostatnich latach w wyniku splotu zróżnicowanych czynników wewnętrznych i zewnętrznych ${ }^{1}$ doszło w kraju do nasilenia się postaw i narracji islamofobicznych w wielu wymiarach życia społecznego i banalizacji poglądów arabofobicznych i islamofobicznych. Jeśli współczesny nacjonalizm jest banalizowany przez codzienne reprezentacje narodu, które rozwijają współdzielone poczucie przynależności narodowej wśród osób przynależących do jednej grupy etniczno-narodowej (Billig 1997), to islamofobia banalizuje się w wyniku rozpowszechniania uproszczonych obrazów i dyskursów na temat wyznawców islamu, zwłaszcza Arabów. W konsekwencji niekwestionowane esencjalistyczne poglądy na temat muzułmanów i islamu podzielają dziś osoby ze wszystkich sfer społecznych,

1 Więcej o tych czynnikach zob. Legut i Pędziwiatr (2018) oraz Pędziwiatr (2016, 2017). 
w każdej grupie wiekowej oraz z każdym poziomem wykształcenia. Badania prowadzone przez Annę Stefaniak w sierpniu 2015 roku pokazały, że jeśli co drugi Polak sprzeciwia się otwartemu nawoływaniu do wypędzenia muzułmanów z Polski, to prawie jedna czwarta mieszkańców kraju udzieliłaby poparcia partii głoszącej tego typu hasła (2015: 17-18). Pomimo licznych badań postaw społeczeństwa polskiego wobec wyznawców islamu, w tym Arabów (m.in. Stefaniak 2015; CBOS 2015, 2016; Skrodzka i Stefaniak 2017) lub badań tego, jak polskie media kształtują obraz muzułmanów i islamu (Bertram et al. 2017), niewiele jest analiz ukazujących, jak te postawy i obrazy są odbierane przez grupę mniejszościową ${ }^{2}$ Celem niniejszego tekstu jest uzupełnienie tej luki i analiza postrzegania transformacji postaw we współczesnym społeczeństwie polskim wobec Arabów z perspektywy członków krajowej społeczności arabskiej i muzułmańskiej. Na poziomie teoretycznym tekst ukazuje również przydatność analityczną koncepcji inności i obcości rozwijanych przez Ewę Nowicką pod koniec lat dziewięćdziesiątych XX wieku.

W początkowej części artykuł nakreśla ramę teoretyczną wykorzystaną do analizy zmiany postaw oraz profil społeczności arabskiej w kraju z perspektywy najnowszych danych statystycznych. W dalszej części ukazuje, jak stosunek społeczeństwa ewoluował od kontrolowanej otwartości i częściowej przychylności - w pewnym stopniu narzuconej przez panujący system polityczny - przez postawy ambiwalentne w okresie transformacji systemowych, do coraz bardziej rosnącego dystansu i niechęci po 2001 roku oraz percepcji tych zjawisk przez Arabów wyznających islam i muzułmanów z innych grup etnicznych mieszkających nad Wisłą.

Tekst jest oparty na analizie źródeł zastanych (między innymi innych publikacjach tematycznych oraz analizie stron internetowych organizacji arabskich i muzułmańskich w kraju) oraz materiałach zgromadzonych podczas badań terenowych. Na te ostatnie składały się przede wszystkim wywiady pogłębione z liderami i przedstawicielami społeczności arabskiej i muzułmańskiej w Polsce ${ }^{3}$, prowadzone w miejscach, gdzie działają główne ośrodki muzułmańskie założone i nadzorowane przez organizacje arabsko-muzułmańskie w kraju, w tym w Warszawie, Krakowie, Gdańsku, Poznaniu, Wrocławiu i Białymstoku4 . Każdy wywiad, przeprowadzany był z użyciem przygotowanego wcześniej scenariusza problematyzującego sytuację społeczności muzułmańskiej w danej lokalizacji oraz jej relacje wewnętrzne (m.in. z różnymi grupami muzułmańskimi) i zewnętrzne (m.in. z lokalną społecznością niemuzułmańską), trwał średnio około 1,5 godziny. Badania terenowe prowadzone były od czerwca 2016 do lutego 2018 roku, najczęściej w formie od trzy- do siedmiodniowych pobytów w każdej z lokalizacji ${ }^{5}$. Wszystkie wywiady zostały starannie przepisane, a kodowanie i analiza były prowadzone z pomocą programu do jakościowej analizy danych NVivo 11. Jedynie niektórzy respondenci wyrazili chęć pozostania anonimowymi, stąd tylko częściowa anonimizacja cytowanego materiału badawczego.

2 Częściowo traktują o tym np. Pędziwiatr (2011) i Switat (2017).

Z wyjątkiem jednego wywiadu przeprowadzanego podczas pobytu badawczego w Wielkiej Brytanii.

4 Jednocześnie badanie intencjonalnie pomijało świeckie lub niemuzułmańskie elity arabskie w Polsce; szerzej zob. Switat (2017), chcąc skupić się nade wszystko na wymiarze arabsko-muzułmańskim. W tym sensie również wnioski z badania odnoszą się przede wszystkim do arabsko-muzułmańskich grup religijnych i mają tylko częściowe zastosowanie do innych grup - np. muzułmanów etniczno-kulturowych (o nich więcej w Pędziwiatr 2007: 42-45) lub osób spoza muzułmańskiej tradycji religijno-kulturowej (np. arabskich chrześcijan).

5 Patrz - pełna lista wywiadów wybranych do analizy projektowej w aneksie. 


\section{GRUPY IMIGRANCKIE JAKO „SWOI” I „OBCY”}

Nauki społeczne od początków swego istnienia interesowały się problematyką poczucia obcości i swojskości w kontekście ludzkiej mobilności oraz w oderwaniu od tego kontekstu. W dobie intensyfikacji procesów globalizacyjnych i polityzacji ruchów wędrówkowych (Castles et al. 2013: 16-17) oraz rosnącego zróżnicowania etniczno-kulturowego współczesnych społeczeństw (Vertovec 2007) zagadnienie to stało się szczególnie istotne. Niektóre z wypracowanych kategorii analitycznych, przydatnych do analizy zjawiska obcości i swojskości oraz postaw wobec ludności napływowej oraz innych kultur to „dystans społeczny” (Florian Znaniecki), „wykluczenie społeczne” (wielu badaczy już od Emila Durkheima i jego studiów nad solidarnością społeczną), „czystość” i ,zmaza/skalanie” (Mary Douglas), ,polityka uznania” (Charles Taylor), ,piętno” (Erving Goffman) i „swój/obcy” (Georg Simmel)6.

Jednym z najbardziej użytecznych w naświetlaniu zmian postaw we współczesnej Polsce wobec arabskości i Arabów oraz postrzegania tych zmian przez członków społeczności arabskiej i muzułmańskiej są moim zdaniem studia nad wykluczeniem społecznym oraz nad obcością i innością. Studium Ervinga Goffmana nad „piętnem społecznym” i mechanizmami jego pojawiania się oraz sposobami radzenia sobie jednostek z tożsamością „zranioną” negatywnym postrzeganiem, zasługuje na szczególną uwagę. Autor pokazuje w nim, że o napiętnowaniu decydują nade wszystko kryteria „,normalności” konstruowane społecznie w każdym społeczeństwie odmiennie. „Piętno” wprowadza „zaburzenie” w rutynę dnia codziennego i zakłóca „normalne” kontakty. Najczęściej tymi elementami zakłócającymi - piętnującymi dane jednostki w określonych kontekstach społecznych - są cechy związane z ciałem i jego wyglądem, cechami charakteru bądź przynależnością grupową, na przykład do określonej klasy społecznej, grupy etnicznej bądź religijnej (Goffman 2005). W przypadku muzułmanów najczęściej mamy do czynienia z tym ostatnim przypadkiem, aczkolwiek nierzadko dochodzą do tego również wcześniejsze elementy (np. sposób ubrania - u kobiet często zasłonięte włosy, lub zachowania - np. abstynencja alkoholowa). Jak pokazuje zgromadzony materiał badawczy (wywiady m.in. z SI, AA, IK) analizowany szerzej poniżej oraz inne studia nad islamem w Europie poczucie „napiętnowania” cechuje wiele społeczności muzułmańskich na naszym kontynencie (EUMC 2006; Fekete i Sivanandan 2009).

Inna bardzo istotna perspektywa analityczna przydatna $\mathrm{w}$ analizie materiału badawczego wywodzi się od Georga Simmela i jego studium nad „obcym”, który „dziś przychodzi, jutro zaś zostaje - niejako potencjalny wędrowiec, który, aczkolwiek nie wyruszył dalej, nie zrezygnował też ze swojej swobody przychodzenia i odchodzenia. Tkwi on przestrzennie [...] W określonym kręgu. Jednak istotnym wyznacznikiem jego pozycji jest fakt, że nie należy on od początku do tego kręgu, że wnosi jakości niebędące i niemogące być rdzennymi właściwościami tego kręgu” (Simmel 2005: 204). Simmel dzieli „obcych” na dwa typy: „znanych” (wewnątrzgrupowych), z którymi istnieje kontakt choćby tylko ograniczony, oraz „,nieznanych” będących poza grupą z powodu przynależności do odmiennej wspólnoty narodowej bądź kulturowej, z którym nie ma przestrzennej bliskości. Co istotne, zwraca on uwagę na

6 Szczegółowe omówienie wielu z tych kategorii można znaleźć między innymi w pracy Jasińskiej-Kani i Łodzińskiego (2009). 
odrębność kulturową, jaka „oddziela” uczestników danego kręgu od osób uznawanych jako „obcych”. „Obcy” mają cechy, które powodują, że w świadomości wspólnoty jawią się jako odmienni (Simmel 2005: 204).

Te refleksje twórczo rozwija Ewa Nowicka zwracająca uwagę między innymi na to, że ktoś może być zakwalifikowany do „obcych” nie tyle na podstawie dystansu fizycznego, ile odległości wykształconej na poziomie poznawczym (odnoszącej się do wiedzy na jego temat) oraz emocjonalnym, skupiającym się na charakterze i stopniu intensyfikacji uczuć skierowanych do „obcych”. „Obcość” jest przeciwieństwem „swojskości” definiowanej w kategoriach poczucia bliskości, poczucia przywiązania i poczucia bezpieczeństwa. Pomiędzy tym, co „obce” i „swojskie” rozciąga się dziedzina „inności”, której granice są nieostre (Nowicka 1996: 23-26).

W ,inności” zawiera się bowiem jednocześnie bardzo istotny pierwiastek pozytywnego zainteresowania i fascynacji ,innym” mało znanym oraz ziarna obaw i strachu przed ,nieznanym”. Jest swoistym mostem przerzuconym między „obcością” i „swojskością”, który może prowadzić zarówno do „oswajania” i zmniejszania dystansu, jak i do jego powiększania. Jak sugeruje Nowicka, dopóki na „innego” patrzymy przez pryzmat obiektywnych różnic lub wywołuje u nas pozytywne emocje, inność pozostaje kategorią neutralną, a z czasem może przekształcić się w „swojskość”. Gdy realna lub wyobrażona obecność „innych” wywołuje negatywne odczucia społeczne, poczucie zagrożenie i niepokoju, to „inność” przekształca się w „obcość” i wizerunek „obcego” łączony jest z obrazem nieprzyjaciela i wroga (Nowicka 1996: 23-26). Podobnie widzi te przemiany Robert Szwed, który zauważa, że jeśli wzmaga się opór przeciw danej ,inności”, a jej obecność niepokoi i wywołuje poczucie braku bezpieczeństwa, to „inny” przekształca się w „obcego”. Jeśli „inność” jest pozytywnie wartościowana, to nie jest obcością, a może nawet przejść w swojskość (Szwed 2003).

Analizując reprezentacje społeczno-kulturowe imigrantów w Polsce w ostatnich dekadach, Aleksandra Grzymała-Kazłowska konstatuje, że w wyniku kilkunastoletnich kontaktów Polaków z cudzoziemcami dochodzi coraz częściej do rosnącego oswojenia i ukonkretnienia kategorii imigrantów w naszym kraju i przeobrażania się ich wizerunków z „innych-obcych” w ,innych-swoich” (Grzymała-Kazłowska 2007: 256-167). Jednocześnie badania autora oraz inne analizy społeczne (m.in. CBOS 2015 i 2018) pokazują, że nowe grupy muzułmańskie w Polsce, zwłaszcza Arabowie, wykluczeni są z tego oswajania i pomimo nierzadko kilkunastoletniej obecności w kraju nie czują, że są postrzegani i traktowani jako pełnoprawni członkowie społeczeństwa polskiego. Jednym z jego ważnych elementów jest wypychanie arabskości i Arabów z przestrzeni publicznej w rezultacie jednoznacznego utożsamienia ich $\mathrm{z}$ islamem ${ }^{7}$, a tego ostatniego jedynie $\mathrm{z}$ jego marginalnymi demograficznie nurtami promującymi przemoc (na przykład tak zwanym Państwem Islamskim).

\footnotetext{
Jak przejrzyście ukazuje Monika Bobako, proces etnicyzowania islamu i utożsamienia go z arabskością ma długą genezę, a w najbardziej dynamiczny sposób przebiegał od XIX wieku, gdy dominujący sposób myślenia o fenomenach ludzkiej kultury w kategoriach „esencji” sprawiał, iż poszukiwano „natury” rzeczy przez docieranie do ich ,początków” i „ukrytej istoty”. W tym ujęciu większość przedstawicieli ummy, którzy nie pochodzą z Półwyspu Arabskiego, nie wyraża tej „esencji”. Druga istotna przyczyna arabizowania islamu wbrew faktom dotyczącym zróżnicowania etnicznego muzułmanów - leży w tendencji do akcentowania europejskiej wyjątkowości kulturowej i odrębności cywilizacyjnej (2017: 154-156).
} 
Arabowie i arabskość są w kraju najczęściej ,innością wyobrażoną”, gdyż na co dzień poza przestrzenią punktów gastronomicznych szybkiej obsługi ma z nimi do czynienia jedynie marginalna część społeczeństwa, ale mają również istotny wymiar społeczny, który należy naświetlić, zanim przejdziemy do dalszej analizy transformacji postaw z perspektywy społeczności arabsko-muzułmańskiej.

\section{SPOŁECZNOŚĆ ARABSKA W POLSCE W ŚWIETLE DANYCH STATYSTYCZNYCH}

W kraju brak jest rzetelnych rejestrów pozwalających na precyzyjne określenie liczby osób poczuwających się do przynależności do muzułmańskiej grupy religijnej czy arabskiej grupy etniczno-kulturowej ${ }^{8}$. Przykładowo istniejące opracowanie przygotowane przez GUS dotyczące przynależności religijnej Polaków błędnie utożsamia członków głównych organizacji muzułmańskich w kraju (nieco ponad pięć tysięcy) z całą społecznością muzułmańską w Polsce (2015). Ta społeczność według szacunków ekspertów jest co najmniej siedem razy większa (Nalborczyk i Pędziwiatr 2018). Jednym ze sposobów na orientacyjne określenie wielkości populacji arabskiej w Polsce jest analiza rejestru osób z krajów arabskich posiadających pozwolenie na pobyt w Polsce. Jednocześnie warto zauważyć, że całkowita liczba Arabów w Polsce może być nawet ponad dwa razy wyższa, niż mówią o tym dane Urzędu do Spraw Cudzoziemców, gdyż część osób z omawianej społeczności (szczególnie wspomniani wyżej członkowie tak zwanej starej diaspory arabskiej - Switat 2017: 208-219) przeszła już drogę naturalizacyjną i nie figuruje w bazach danych UDSC, a część osób w ogóle nie rejestruje swojego pobytu w Polsce. Ponadto Arabowie europejscy pochodzący na przykład z Francji, mającej jedną z najliczniejszych społeczności muzułmańskich w Europie (Pędziwiatr 2007: 49-51), pozostaną niewidoczni w aktualnych rejestrach.

Według danych z kwietnia 2018 roku w Polsce zamieszkuje nieco ponad osiem tysięcy osób z dwudziestu dwóch krajów arabskich przynależących obecnie lub w niedalekiej przeszłości ${ }^{9}$ do Ligii Państw Arabskich (dalej LPA), która zrzesza państwa powiązane wspólnotą języka, historii, kultury i religii. Najliczniejsze (ponad tysięczne) grupy obywateli krajów arabskich zarejestrowane przez UDSC pochodzą z Egiptu (powyżej 16\% całości), Iraku (powyżej 14\%) i Syrii (13\%) (zob. tabela 1). Stanowią je najczęściej osoby młode $\mathrm{w}$ wieku od dwudziestu do trzydziestu dziewięciu lat z mniejszością osób w przedziałach wiekowych powyżej czterdziestu lat i poniżej dwudziestu lat. Ponad 6,5 tysiąca osób to mężczyźni, a mniej niż 1,5 tysiąca - kobiety, co wskazuje na brak zrównoważenia płciowego cechujący wczesne stadia migracji osób z krajów Afryki Północnej i Bliskiego Wschodu.

8 Warto oczywiście podkreślić, że te dwie grupy w żaden sposób nie są tożsame, o czym traktowaliśmy powyżej, a co bardzo często umyka rodakom. Najnowsze dane szacunkowe na ten temat można znaleźć na przykład w pracy Kościelniaka (2016: 359-368).

9 Na przykład Syrii mającej zawieszone członkostwo w LPA od początku wojny domowej. 
Transformacje postaw wobec Arabów w społeczeństwie polskim...

Tabela 1. Obywatele krajów LPA przebywający aktualnie w Polsce ${ }^{10}$

\begin{tabular}{|l|c|l|c|}
\hline \multicolumn{1}{|c|}{ Kraj } & Liczba & \multicolumn{1}{|c|}{ Kraj } & Liczba \\
\hline Egipt & 1323 & Palestyna & 115 \\
\hline Irak & 1168 & Kuwejt & 68 \\
\hline Syria & 1056 & Sudan & 43 \\
\hline Tunezja & 865 & Oman & 43 \\
\hline Arabia Saudyjska & 842 & Somalia & 35 \\
\hline Algieria & 726 & Katar & 11 \\
\hline Maroko & 540 & Zjednoczone Emiraty Arabskie & 11 \\
\hline Libia & 443 & Bahrajn & 7 \\
\hline Liban & 307 & Komory & 3 \\
\hline Jordania & 290 & Dżibuti & 1 \\
\hline Jemen & 156 & Mauretania & 0 \\
\hline
\end{tabular}

Na takie wczesne stadium migracji wskazują również typy pozwoleń na pobyt, jakie posiadają obywatele krajów Ligii Państw Arabskich w Polsce. Zdecydowana większość ma jedynie pozwolenie na pobyt czasowy. Jest to na przykład przypadek zdecydowanej większości z ponad 800 obywateli saudyjskich przebywających w Polsce w celach edukacyjnych. Jednocześnie prawie co czwarty imigrant z krajów LPA ma pozwolenie na pobyt stały lub pobyt rezydenta długoterminowego. Jedynie 5\% (406 osób) spośród wszystkich obywateli krajów Ligii zamieszkujących Polskę to osoby posiadające status uchodźcy, a niecałe 140 osób podlega ochronie uzupełniającej ${ }^{11}$.

Obywatele krajów arabskich zamieszkują wszystkie części kraju, choć zdecydowanie najczęściej ubiegają się o uzyskanie pozwolenia na pobyt wydawanego przez wojewodę mazowieckiego i łódzkiego (ponad połowa pozwoleń) lub przez szefa UDSC. Ich liczba w ciągu ostatnich ośmiu lat wzrosła czterokrotnie. Jeśli w 2010 roku w kraju zarejestrowanych było w UDSC trochę ponad dwa tysiące osób, to w kolejnych latach nastąpił znaczący wzrost tej liczby. Jak można zaobserwować na mapie, ten przyrost najszybciej przebiegał w województwie lubelskim (ponadsześciokrotny), a najwolniej w województwie lubuskim (trochę ponad dwukrotny - zob. rysunek 1).

Wśród tej ponadośmiotysięcznej grupy jest prawie 1,7 tysiąca osób studiujących na polskich uczelniach wyższych. Spośród nich zdecydowanie najliczniejszą grupę - ponad 800 osób - stanowią obywatele Arabii Saudyjskiej studiujący w Polsce najczęściej medycynę, a prawie ćwierć tysiąca z nich to kobiety. Dość liczne (ponadpięćdziesięcioosobowe) grupy studentów tworzą obywatele Iraku, Egiptu, Libanu, Maroka, Kuwejtu i Omanu. Mniejsze społeczności studenckie tworzą studenci przybyli do Polski z Palestyny, Libii, Jordanii i Jemenu, a najmniejsze (poniżej trzydziestu osób) obywatele pozostałych krajów Ligi Państw

10 Opracowanie własne na podstawie danych UDSC - stan na 1 kwietnia 2018 roku.

11 UDSC. Statystyki migracyjne dostępne na stronie migracje.gov.pl [20.04.2018]. 
Arabskich. Wśród wszystkich studentów arabskich w kraju ponad jedną czwartą stanowią osoby, które stosunkowo niedawno przybyły do Polski i są dopiero na pierwszym roku studiów (GUS 2017).

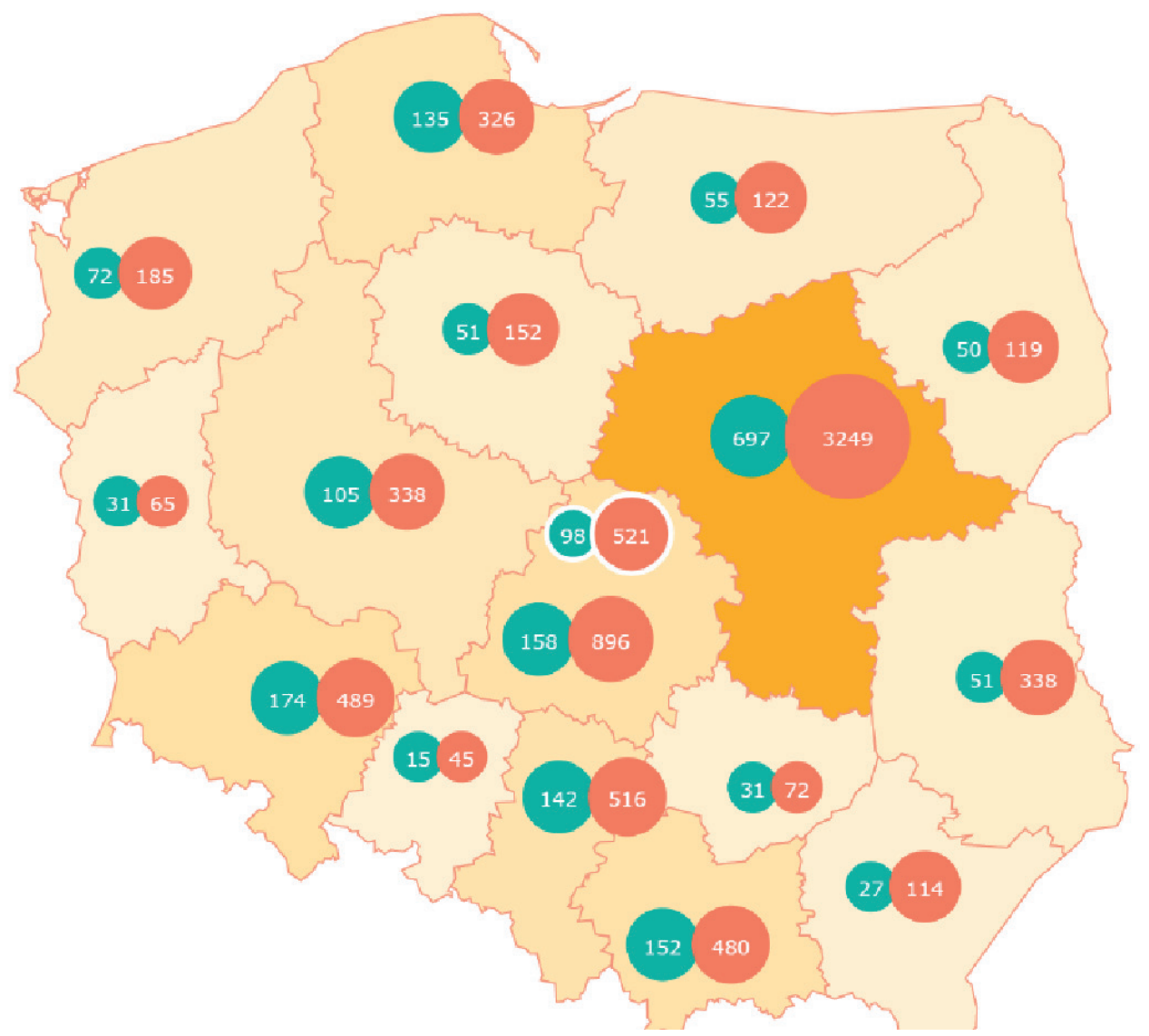

Rysunek 1. Obywatele krajów LPA posiadający zezwolenie na pobyt w kraju w roku 2010 (dane z lewej - zielone tło) oraz w roku 2018 (dane z prawej - czerwone tło) ${ }^{12}$

\section{ARABSKA INNOŚĆ}

Początki dzisiejszej społeczności arabskiej w Polsce, a tym samym kontaktów współczesnych Polaków z Arabami w kraju mają swoją genezę w powojennej Polsce. Pomimo że Polska pod rządami komunistycznymi była nieoficjalnie „krajem zamkniętym”, o czym

12 Opracowanie własne na podstawie danych UDSC - stan z kwietnia 2018 roku. 
najlepiej może świadczyć fakt, że w 1952 jedynie około pięćdziesięciu osób dostało paszport na prywatny wyjazd na Zachód (Stola 2010: 10), to władze nie zdołały szczelnie zamknąć granic państwa. Jedną z nielicznych grup, która imigrowała do Polski w momencie, gdy spora grupa obywateli polskich marzyła o opuszczeniu kraju, byli Arabowie. Do końca lat osiemdziesiątych ubiegłego wieku ta migracja dotyczyła przede wszystkim sfery edukacyjnej. Polska była jednym z państw, które pozytywnie odpowiedziały na apel ONZ o udzielenie pomocy edukacyjnej krajom rozwijającym się, w tym krajom Bliskiego Wschodu i Afryki Północnej, i oferowała kształcenie kadr na warunkach pełnego stypendium rządu polskiego. Oprócz studentów „z bratnich krajów komunistycznych” (najwięcej z Chin i Wietnamu) już od końca lat pięćdziesiątych do PRL zaczęli przybywać pierwsi stypendyści z takich krajów arabskich, jak Syria, Jemen, Irak czy Sudan (Chilczuk 2001).

Po otwarciu ambasad Syrii i Iraku - gdy PZPR rozprawiła się z tak zwanym „odchyleniem żydowskim" (w 1968 roku) - kooperacja nie tylko edukacyjna, ale również polityczna, ekonomiczna i kulturowa z państwami arabskimi nabrała dalszego rozpędu i liczba studentów muzułmańskich systematycznie wzrastała. Jak barwnie ukazuje to Gasztold-Seń (2012) na podstawie archiwalnych dokumentów wywiadu, pobyt studentów arabskich w Polsce nie zawsze związany był jedynie z nauką, a czasami z wypoczynkiem, rozrywką i ucieczką. Praktyka religijna często była przez nich ignorowana, a dodatkowo władze PRL nie tolerowały sympatyzowania i prób organizowania się przez studentów w ramach międzynarodowych struktur Bractwa Muzułmańskiego. Z rozrywkami studentów arabskich miała do czynienia również jedna z liderek społeczności tatarskiej w Białymstoku. Tak po wielu latach wspomina te epizody: „Część studentów arabskich, którzy byli zakwaterowani w jednym internacie [...], strasznie rozrabiała, bo w domu to byli święci, a tutaj urwali się. Posprowadzali sobie dziewczyny i kierownik internatu nie radził sobie z nimi. To ja mówię do niego, niech pan poprosi ich tutaj na rozmowę, przedstawi pan mnie i pan powie, że będę ich opiekunką. [...]. Wszyscy przyszli w swoich strojach narodowych. [...] Dyrektor powiedział, że moja zastępczyni jest muzułmanką, Tatarką, zna religię, w związku z czym będzie się wami opiekowała i będzie wam łatwiej. Od tego czasu był spokój. Ha, ha..." [śmiech] (Wywiad z HS).

W Białymstoku lokalna społeczność muzułmańska pomagała zaadaptować się studentom arabskim do warunków życia w Polsce, a ci ostatni między innymi poprzez prowadzenie działalności edukacyjnej odegrali ważną rolę w rewitalizacji islamu w Polsce. W tym mieście również po części dzięki interakcjom z autochtoniczną społecznością muzułmańską doszło do powstania pierwszej imigranckiej organizacji arabsko-muzułmańskiej w Polsce: Stowarzyszenia Studentów Muzułmańskich (SSM) oraz pierwszego centrum muzułmańskiego z salą modłów ${ }^{13}$ zakupionego przez Muzułmańskie Stowarzyszenie Kształcenia i Kultury (MSKK). Ta ostatnia organizacja z siedzibą w Białymstoku jest również właścicielem innych obiektów użytkowanych przez Ligę Muzułmańską (LM), a znaczna część liderów Ligi, z aktualnym i byłym przewodniczącym tej organizacji na czele, mają w swych życiorysach krótszy bądź dłuższy epizod pobytu w mieście. Jeden z nich - aktualny przewodniczący organizacji w ten sposób pamięta tamten okres: „Bardzo dobrze wspominam tamte czasy. Mieliśmy bardzo dobre relacje ze społecznością lokalną. Paniami Szahidewicz i Korycką. [...] To był

\footnotetext{
13 Przy ulicy Hetmańskiej.
} 
bardzo dobry czas dla nas [...] nawet była taka komisja koordynacyjna pomiędzy naszymi instytucjami, tzn. Stowarzyszeniem Studentów Muzułmańskich i Muzułmańskim Związkiem Religijnym ${ }^{14 "}$ (wywiad z YC).

W późniejszych latach ta współpraca pomiędzy muzułmańską społecznością imigracyjną animowaną przez Arabów oraz społecznością tatarską zaczęła słabnąć między innymi ze względu na różnice ideowe oraz odmienne strategie działania (wywiad z TM, HS i KR), a także obawy części Tatarów o przejęcie kontroli nad MZR przez Arabów (wywiady z YC i APSA1). Efektem było powstanie w kwietniu 2001 alternatywnej wobec MZR organizacji muzułmańskiej - Ligii Muzułmańskiej - konkurującej z nią o wpływy w polskiej populacji muzułmańskiej ${ }^{15}$.

Oficjalne statystyki mówią o tym, że między 1950 i 2000 rokiem dyplomy polskich uczelni zdobyło 872 obywateli Iraku, 778 - Syrii, 311 - Sudanu, 290 - Jemenu, 188 - Jordanii i 125 - Tunezji, by wymienić tylko najliczniejsze grupy spośród krajów LPA ${ }^{16}$. Najczęściej kończyli oni studia medyczne, biznesowe, administracyjne lub humanistyczne (Chilczuk 2001). W ogólnej liczbie absolwentów cudzoziemskich polskich uczelni okresu komunistycznego osoby z krajów arabskich stanowiły najliczniejszą grupę studentów. Warto zaznaczyć jednak, że większość z nich po zakończeniu studiów powróciła do swoich krajów, a jedynie część założyła w Polsce rodziny i tym samym stworzyła podwaliny pod rozwój imigranckiej społeczności muzułmańskiej w Polsce.

Do końca lat osiemdziesiątych XX wieku wizerunek Arabów w mediach i społeczeństwie polskim był w znacznym stopniu neutralny, gdyż nie tylko dbała o to cenzura, nieprzyzwalająca na to, by obywatele krajów zaprzyjaźnionych byli ukazywani w sposób negatywny, lecz również jeśli Polacy wchodzili w interakcje z Arabami na terenie kraju, to byli to przede wszystkim studenci i inni przedstawiciele klasy średniej. Jeden z nich tak wspomina swój pierwszy etap pobytu w Polsce „Ja tutaj przyjeżdżałem od 1987 roku [...] Bardzo dobrze wspominam ten okres. Miałem bardzo dobre relacje z innymi. Rzadko spotykałem się z czymś innym" (wywiad z IK). Wspomnienia innych przedstawicieli społeczności arabskiej, którzy przybyli do Polski w czasach PRL zasadniczo nie odbiegają od powyższej opinii (m.in. wywiady z APSA1, NC, AEA). Choć byli świadomi swojej ,inności”, to była ona odbierana społecznie nade wszystko w sposób neutralny, a w niektórych wymiarach wręcz pozytywny. Jak zauważali respondenci Mustafy Switata ze społeczności arabskiej przebywający w Polsce od kilku dekad, przed 1989 rokiem przyczyną negatywnego postrzegania były przede wszystkim różnice majątkowe, a nie religijne (2017: 355-356).

Ta sytuacja powoli zaczęła ulegać zmianie po 1989 roku i narodzinach wolnych mediów. Towarzyszył im między innymi wzrost dywersyfikacji opinii na temat Arabów, islamu i muzułmanów (Nalborczyk 2004). Stopień krytycyzmu krajowych mediów wobec tych ostatnich już w latach dziewięćdziesiątych zaczął wzbudzać zaniepokojenie krajowych ekspertów. Jeden

14 MZR - najstarsza organizacja muzułmańska w kraju założona w 1925 roku i od tamtej pory pozostająca w rękach tatarskich.

15 Część liderów społeczności arabskiej tłumaczy powstanie LM również chęcią uszanowania tatarskiego charakteru MZR (m.in. wywiady z YC i APSA1).

16 Te same statystyki milczą na temat osób, które przyjechały na studia do Polski i z różnych względów nie zdołały ich ukończyć. Ta liczba mogłaby być nawet dwukrotnie wyższa. 
z nich na długo przed początkiem „wojny z terroryzmem” alarmował, że „Ani w Niemczech, ani $\mathrm{w}$ Wielkiej Brytanii, gdzie istnieją większe problemy z imigrantami ze świata muzułmańskiego, prasa nie jest tak krytyczna w stosunku do nich jak w Polsce” (Janusz Danecki cytowany w „Rzeczpospolitej” (1994)).

Bardzo szybko do tych narracji prasowych zaczęły dostosowywać się również wyobrażenia społeczne. Z badań Ewy Nowickiej dowiadujemy się, że już w latach 1990 stereotypowy Arab w oczach wielu Polaków jawił się jako leniwy, fałszywy, brudny, agresywny, interesowny, nieszanujący kobiet i przesadnie religijny (Nowicka 1990). W późniejszych latach te stereotypowe wyobrażenia czerpiące z długiej historii niezrozumienia i orientalizmu (Said 1978) były jedynie wzmacniane między innymi przez media. Jak słusznie zauważa Vincent Geisser, kwintesencją islamofobii medialnej jest nie tyle demonizowanie muzułmanów w środkach masowego przekazu - gdyż żaden profesjonalny dziennikarz nie dąży a priori do tego, by zaprezentować negatywny obraz wiernych islamu - ile tendencja do ujednolicania uzyskanych od nich opinii i upraszczanie ich w taki sposób, aby wpisywały się w istniejące wyobrażenia. Po zamachach na WTC i Pentagon 11 marca 2001 roku przeprowadzonych przez komando arabskie złożone w większości z obywateli Arabii Saudyjskiej teza o zderzeniu cywilizacji została znacząco wzmocniona i stereotypowe obrazy uległy jedynie petryfikacji. Otwarcie granic i polskie spotkania $\mathrm{z}$ arabskością podczas pobytów turystycznych w krajach arabskich (np. wyjazdów do Egiptu) nie były w stanie oprzeć się tym hegemonicznym narracjom. Jak zauważają badacze teorii kontaktu, faktyczna zmiana uprzedzeń zależy bowiem nie od kontaktu z różnorodnością w ogóle, ale od tego, jak znaczące oraz jak bardzo pogłębione jest określone spotkanie z innością (Valentine 2010: 519). Nie bez znaczenia jest również to, z jakiego typu innością mamy do czynienia. Jak pokazała między innymi Young, bliski kontakt z niektórymi typami inności może rodzić chęć obrony i odgradzania się (Young 1990). Od 2001 roku możemy zaobserwować w Polsce zdecydowane tendencje to tego typu działania, pomimo że ten inny-obcy jest $\mathrm{z}$ reguły wyobrażony i zapośredniczony medialnie.

\section{ARABSKA OBCOŚĆ}

W rezultacie zamachu terrorystycznego z 11 września 2001 roku XXI wiek rozpoczą1 się z jasno zdefiniowanym obcym w postaci muzułmanów, a w szczególności Arabów. Kategorie arabskości i Arabów przestały nieść w sobie neutralny ładunek ,inności” i zaczęły ewoluować w kierunku „obcości” wywołującej silne negatywne odczucia społeczne oraz poczucie zagrożenia i niepokoju. Jak słusznie zauważa Sara Ahmed, „obcy” - w naszym przypadku Arabowie - tak naprawdę nie są nam całkowicie obcy. Przeciwnie, „obcy” są nam już znani, ponieważ już ich rozpoznajemy jako „obcych” (Ahmed 2000). Nie musimy ich wcale spotykać, żeby rozpoznawać ich jako „obcych”. Posiadana szczątkowa wiedza na temat „obcych” jest uzupełniana obrazami medialnymi z linii rzekomego frontu ,wojny cywilizacji” - jak bardzo często przedstawiane są wydarzenia z prowadzonej od 2001 roku „wojny z terrorem”. Udział polskiej armii, między innymi w operacji militarnej w Iraku i związane z nią ofiary w ludziach, jak również ataki terrorystyczne, w których ginęli Polacy (m.in. w Madrycie w 2004 roku i Londynie w roku 2005 czy późniejsze) sprawiły, że krajowy 
przekaz medialny na temat Arabów, islamu i muzułmanów uległ w wielu aspektach jeszcze dalej posuniętej esencjonalizacji i demonizacji i znalazł nowe pola do udowadniania tezy o ich rzekomej ,naturalnej skłonności do przemocy i agresji”.

Powyższe typy narracji jednoznacznie wzmacniające reprezentacje społeczno-kulturowe Arabów jako obcych uległy chwilowej zmianie w początkowej fazie arabskiej wiosny, kiedy to terminy Arabów i arabskości przestały być wiązane jedynie z przelewem krwi, fundamentalizmem i autorytaryzmem, a zaczęto je łączyć z dążeniem do wolności, walką bez przemocy, ekspresją artystyczną i demokracją. W miarę jak fala rewolucyjna przetoczyła się przez kraje regionu Afryki Północnej i Bliskiego Wschodu i do głosu zaczęły dochodzić siły kontrrewolucyjne, a konflikty zbrojne, które wywołała (np. w Syrii oraz Libii), zaczęły zataczać coraz szersze kręgi, to ,arabskość” szybko wpisała się na nowo w kategorie „obcości”. Jednym ze zjawisk egzogennych, które w największym stopniu w ostatnich latach przypisało jej takie cechy, to działania tak zwanego Państwa Islamskiego (Daesz) w Iraku i Syrii oraz zamachy terrorystyczne przeprowadzane przez członków i sympatyków tej organizacji w różnych częściach globu. Dodatkowe zjawiska, które wzmocniły narracje o arabskiej obcości, to przyspieszenie procesów sakralizacji narodu oraz polityzacja i sekurytyzacja imigracji w kontekście tak zwanego kryzysu migracyjnego. Te pierwsze procesy mają długą historię i manifestują się znaczącym wpływem katolicyzmu na rozwój polskiego nacjonalizmu i tożsamości narodowej ${ }^{17}$. Jak słusznie zauważa Michał Buchowski, w kraju istnieje silne przenikanie się katolicyzmu i nacjonalizmu, a Polska jest konstruowana jako hybryda święto-świecka (Buchowski 2016: 51-67). W ostatnich latach te procesy uległy znaczącej intensyfikacji między innymi w rezultacie sojuszu pomiędzy konserwatywną częścią Kościoła katolickiego w Polsce i klasy rządzącej. Ich efektem jest przekształcanie świeckiego narodu w twór uświęcony, któremu zagrażają nie tylko „obcy” kulturowi, ale przede wszystkim religijni. Wśród tych ostatnich muzułmanie/Arabowie ${ }^{18}$ odgrywają najważniejszą rolę ${ }^{19}$.

Te procesy są również bardzo dobrze dostrzegane przez członków polskiej społeczności muzułmańskiej (m.in. wywiady z YC, APSM, AB, MT i APST). W najbardziej celny sposób ujął je jeden z przedstawicieli polskiej społeczności szyickiej, mówiąc: „W ciągu ostatnich lat widzi się wyraźną zmianę i dyskurs katolicki jest w jakimś tam sensie przejmowany właśnie przez ruchy nacjonalistyczne [...] i to, co jest do tej pory mi się zawsze kojarzyło z dialogiem na poziomie oficjalnym, teraz coraz bardziej zaczyna mi się kojarzyć z tym dyskursem, takim narodowo-katolickim, gdzie ta ciekawość i dialog oczywiście już się przemienia w coś zupełnie innego”. Ponadto dodaje: „Tego typu dyskurs narodowo-katolicki to zawsze była po prostu skineria. Dzisiaj to się stało o wiele bardziej mainstreamowe" (wywiad z AM).

17 Patrz między innymi Janion (2006) i Łuczewski (2012).

18 Tu warto wspomnieć, że nie wszystkie grupy muzułmańskie w Polsce są w równym stopniu zainteresowane aktywnym przeciwdziałaniem zjawisku islamofobii. Przykładowo część przywódców tatarskich z Muzułmańskiego Związku Religijnego, prezentujących się jako „muzułmanie europejscy” (wywiad z TM i APST), do niedawna starała się ten problem bagatelizować lub go w ogóle nie dostrzegać.

19 Dobrą ilustracją tych procesów jest kibicowskie graffiti z ulic Krakowa głoszące „Każdy arab (sic) niech pamięta, dla nas Polska to rzecz święta” ze znakami zakazu dla z minaretów i ISIS w tle. Co znamienne, sąd nie podzielił zdania policji, że to graffiti nosi znamiona nawoływania do nienawiści i nie pociągnął jego autorów do odpowiedzialności karnej. Zdjęcie graffiti: Pędziwiatr (2017), a informacja o wyroku: PCh24 (2018). 
Inny proces, który budzi szczególne zaniepokojenie w społeczności arabskiej oraz w znacznej części społeczności muzułmańskiej, to bezprecedensowa polityzacja i sekurytyzacja imigracji, której punkt kulminacyjny zbiegł się z polskimi wyborami parlamentarnymi w 2015 roku, lecz bynajmniej po nich nie przeminą ${ }^{20}$. Tym sposobem imigracja, która w przeciwieństwie do krajów imigracyjnych Europy Zachodniej nie była do tej pory wykorzystywana w walce politycznej, stała się ważnym orężem wyborczym i postwyborczym, a figura arabskich/muzułmańskich uchodźców przedstawianych jako zakamuflowani najeźdźcy była kluczowym elementem tej strategii mobilizacyjnej. Jednym z jej elementów było stworzenie przestrzeni w mediach państwowych podporządkowanych koalicji rządzącej dla narracji otwarcie antyimigracyjnej i antymuzułmańskiej. W ten sposób te procesy widzi jeden z przedstawicieli społeczności arabskiej w Polsce: „W ostatnich latach słyszymy i widzimy dużo więcej ataków ze strony mediów przeciwko islamowi i muzułmanom. Tego się boimy po prostu. Często do centralnych mediów zapraszani są goście, którzy są znani z nienawiści do islamu, do muzułmanów. [...] Pani Miriam Shaded nawet ma plan, żeby zakazać islamu w całej Europie" (wywiad z IK).

Te obawy nie są bezpodstawne, co pokazują statystyki Prokuratury Krajowej potwierdzające wzrost przestępstw o charakterze ksenofobicznym szczególnie wobec muzułmanów (Prokuratura Krajowa 2016). W ostatnich latach doszło również do kilku ataków na meczety - w szczególności te prowadzone przez Ligę Muzułmańską. Podczas jednego z ostatnich (w listopadzie 2017 roku) porozbijano szyby w meczecie na Ochocie (Metro 2017). Szef Ligii jednoznacznie przyczynę tego typu zajść widzi w panice moralnej tworzonej przez polityków i „zaprzyjaźnione” media. „Ci, którzy rozbili szyby w naszym meczecie ostatnio, to myślę, że też oglądali TVP1 albo TVP Info i myślą, że to, co tam mówią o muzułmanach, to jest prawda. Myślą, że to muzułmanie, więc trzeba ich zniszczyć”. Jednocześnie krytykuje klasę polityczną, mówiąc: „Nigdzie nie słyszałem od obecnego rządu, żeby apelowali do ludzi, by byli sprawiedliwi wobec muzułmanów, którzy żyją tutaj. Nasza wspólnota jest bardzo wykształcona, robimy dużo czegoś dobrego dla Polski, ale nigdy nie słyszymy słów uznania. Ani od premiera, ani prezydenta, nic... [...] To jest ich porażka" (wywiad z YC).

Przedstawiciele społeczności arabskiej bardzo często w wywiadach twierdzili, że wielokrotnie byli przedmiotem ataków werbalnych (szczególnie za pośrednictwem internetu) i że czują się napiętnowani przez ciągłe oskarżenia o szerzenie fundamentalizmu i radykalizmu oraz rzekomą chęć islamizacji Polski i Europy (m.in. wywiady z AA, APSA2 i NC). Jeden z nich wyznał, że nie tylko znaczna część społeczeństwa, ale również politycy jego zdaniem „myślą, że jesteśmy terrorystami, pomimo tego, że widzą naszą działalność i wiedzą, że ABW sprawdza nas w dzień i noc" (wywiad z AA).

Ponadto uskarżali się na nierówne traktowanie przez instytucje rządowe, szczególnie w porównaniu z innymi społecznościami muzułmańskimi w kraju, zwłaszcza z Tatarami. To nierówne traktowanie wielu postrzega jako formę symbolicznego wykluczania nie tylko ze społeczności narodowej, ale również z krajowej społeczności muzułmańskiej (m.in. wywiady z APSA1, IK i YC). Aktualny szef Ligii formułuje te zarzuty najbardziej przejrzyście, mówiąc: „Rząd faworyzuje bardzo MZR i to widać w ich spotkaniach [...]. Kiedy jest jakaś

20 Szerzej o tych procesach w pracy Legut i Pędziwiatra (2018). 
uroczystość, to zawsze jest mufti Miśkiewicz. A my? My jesteśmy organizacją, która jest silniejsza nawet niż MZR i też mamy naszego muftiego. Dlaczego nie jesteśmy zaproszeni? Dlaczego nasz mufti nie jest zaproszony? Dlaczego jesteśmy na marginesie?” (wywiad z YC).

\section{KONKLUZJE}

Niniejszy tekst przeanalizował transformacje postaw wobec Arabów w Polsce oraz percepcję tych zmian przez liderów i przedstawicieli społeczności arabskiej i muzułmańskiej, wypełniając tym samym ważną lukę w analizach uprzedzeń antymuzułmańskich i antyarabskich. Warto zauważyć, że aktualne łączenie arabskości i Arabów z obcością, wywołujące silne negatywne odczucia społeczne oraz poczucie zagrożenia, nie może być zrozumiane w oderwaniu od współczesnych wydarzeń politycznych oraz ich mediatyzacji zarówno w mediach tradycyjnych, jak i w mediach społecznościowych. Jak pokazują badania społeczne, to media społecznościowe są nade wszystko odpowiedzialne za strukturalne rozdrobnienie internetowej sfery publicznej, w której internauci, pomimo istnienia szerokiego wyboru źródeł informacji, poszukują tych treści, które wzmacniają ich uprzedzenia, pozwalając im uniknąć skonfrontowania się z różnicą (Dahlberg 2007: 828-832). Jednocześnie nie można zapominać o tym, że postrzeganie Arabów jako „innych-obcych” ma długą historię i powiązane jest z ich orientalnymi (w znaczeniu, jakie nadał temu słowu Edward Said (1978)) i urasowionymi ${ }^{21}$ (od rasizmu) stereotypami jako tymi, którzy są cywilizacyjnie odmienni od nas i zdeterminowani religijnie/kulturowo do określonych typów zachowań. W tym ujęciu ich negatywne reprezentacje wynikają nie z ,naturalnego” lęku wobec inności będącego rezultatem ograniczonych kontaktów, lecz są reakcjami silnie skorelowanymi z utrwalonymi (m.in. przez media), uproszczonymi obrazami islamu i jego wiernych, głęboko osadzonymi w orientalistycznych dyskursach o muzułmańskiej odmienności.

Społeczne zainteresowanie arabską ,innością”, pomimo że zostało w ostatnich dekadach silnie zagłuszone przez narracje „obcości” mające na celu wywołanie obaw i strachu, wciąż daje się zauważyć w części społeczeństwa polskiego. Społeczność arabska w kraju dostrzega te elementy między innymi podczas takich wydarzeń, jak na przykład Noc Świątyń. Jeden z opiekunów meczetu na Ochocie w ten sposób wspominał drugą edycję tej inicjatywy w Warszawie we wrześniu 2016 roku: „To było wielkie zaskoczenie dla nas. Przygotowaliśmy się, że przyjdzie 35-50 osób i na tyle osób przygotowaliśmy miejsc [...]. Tylko na pierwszą turę przyszło prawie tysiąc osób. Więc byliśmy mile zaskoczeni” (wywiad z AA). Opiekun innego meczetu warszawskiego przynależącego do MZR stara się natomiast nie zrażać negatywnymi doświadczeniami ataków werbalnych i fizycznych i dalej prowadzić swoją działalność, „Mimo, że ostatnio coraz więcej jest głosów, że ta tolerancja zaczyna spadać [...], ja wychodzę w tych ubraniach (tradycyjnych ubraniach arabskich - galabiji) i czasem podróżuję w nich razem z żoną i dzieckiem [...]. Gdy jacyś pijani albo osoba pod wpływem alkoholu atakuje nas, to Polacy nas bronią. Było kilka przypadków takich, że Polacy nas bronili i nie pozwolili skrzywdzić" (wywiad z NC). Te doświadczenia dnia codziennego sprawiają, że

21 Występujący w sytuacjach, gdy muzułmańska/arabska „kultura” ujmowana jest w skrajnie deterministyczny i esencjalistyczny sposób, stając się tym samym funkcjonalnym ekwiwalentem biologicznie rozumianej ,rasy”. 
Transformacje postaw wobec Arabów w społeczeństwie polskim...

on sam, a wraz z nim wielu innych przedstawicieli społeczności nadal wierzy w możliwości akceptacji inności arabskiej przez społeczeństwo polskie oraz wzmocnienia się w przyszłości postrzegania arabskości z perspektywy inności, a nie obcości.

\section{BIBLIOGRAFIA}

Ahmed, Sara. 2000. Strange Encounters: Embodied Others in Post-Coloniality, London New York: Routledge.

Berkley Centre. 2018. Demographics of Islam, https://berkleycenter.georgetown.edu/essays/ demographics-of-islam [5.04.2018].

Bertram, Łukasz, Adam Puchejda i Karolina Wigura. 2017. Negatywny obraz muzułmanów w polskiej prasie, Raport Obserwatorium Debaty Publicznej „Kultury Liberalnej”, https:// www.rpo.gov.pl/sites/default/files/Raport_Negatywny_obraz_muzulmanow_w_polskiej_ prasie_Analiza_wybranych_przykladow_z_lat_2015_2016.pdf [15.04.2019].

Billig, Michael. 1997. Banal Nationalism, London: Sage Publications.

Bleich, Erik. 2011. What Is Islamophobia and How Much Is There? Theorizing and Measuring an Emerging Comparative Concept, „American Behavioral Scientist”, 55, 12: 1581-1600.

Bobako, Monika. 2017. Islamofobia jako technologia władzy: studium z antropologii politycznej, Kraków: TAiWPN Universitas.

Buchowski, Michał. 2016. Making Anthropology Matter in the Heyday of Islamophobia and the 'Refugee Crisis': The Case of Poland, „Český lid”, 103: 51-67.

Castles, Steven, Hein de Haas i Mark J. Miller. 2013. The Age of Migration: International Movements in the Modern World, Houndmills: Macmillan Publishers.

CBOS. 2015. Postawy wobec islamu i muzułmanów (Attitudes towards Islam and Muslims), Warszawa: Centrum Badania Opinii Społecznej.

CBOS. 2018. Stosunek Polaków do innych narodów, Warszawa: Centrum Badania Opinii Społecznej.

Chilczuk, Michał. 2001. 50 lat ksztatcenia studentów zagranicznych w Polsce, http://www. copernicus.org.pl/kontakt/chilczuk.htm [9.05.2018].

Dahlberg, Lincoln. 2007. Rethinking the fragmentation of the cyber public: from consensus to contestation, „New Media \& Society”, 9, 5: 827-847.

EUMC. 2006. Muslims in the European Union: Discrimination and Islamophobia, http:// eumc.europa.eu/eumc/material/pub/muslim/Manifestations_EN.pdf [5.03.2018].

Fekete, Liz i Ambalavaner Sivanandan. 2009. A Suitable Enemy: Racism, Migration and Islamophobia in Europe, London: Pluto Press.

Gasztold-Seń, Przemysław. 2012. Arabscy studenci w Warszawie po 1956, w: Patryk Pleskot (red.), Cudzoziemcy w Warszawie 1945-1989: studia i materiaty, Warszawa: Instytut Pamięci Narodowej, s. 41-72.

Goffman, Eric. 2005. Piętno. Rozważania o zranionej tożsamości, Gdańsk: Gdańskie Wydawnictwo Psychologiczne.

Grzymała-Kazłowska, Aleksandra. 2007. Konstruowanie „,innego”: wizerunki imigrantów w Polsce, Warszawa: Wydawnictwa Uniwersytetu Warszawskiego.

GUS. 2015. Struktura narodowo-etniczna, językowa i wyznaniowa ludności Polski, Warszawa: Główny Urząd Statystyczny. 
GUS. 2017. Szkoły wyższe i ich finanse w roku 2016, Warszawa: Główny Urząd Statystyczny. IOM. 2016. Badanie na temat postaw wobec cudzoziemców w Polsce, Warszawa: International Organisation of Migration.

Janion, Maria. 2006. Niesamowita Stowiańszczyzna, Kraków: Wydawnictwo Literackie.

Jasińska-Kania, Aleksandra i Sławomir Łodziński (red.). 2009. Obszary i formy wykluczenia etnicznego w Polsce, Warszawa: Wydawnictwo Naukowe Scholar.

Kościelniak, Krzysztof. 2016. Muzulmanie - charakterystyka społeczno-kulturowa w kontekście imigracji do Polski, w: Jacek Schmidt i Dariusz Niedźwiedzki (red.), Społeczno-kulturowa identyfikacja cudzoziemców. Raporty i ekspertyzy, Poznań: Wydawnictwo Naukowe UAM, s. 353-488.

Legut, Agnieszka i Konrad Pędziwiatr. 2018. Sekurytyzacja migracji w polityce polskiej a zmiana postaw Polaków wobec uchodźców, w: Romuald Jończy (red.), Sami swoi? Wielokulturowość we współczesnej Europie, Gliwice-Opole: Dom Współpracy Polsko-Niemieckiej, s. 41-51.

Łuczewski, Michał. 2012. Odwieczny naród. Polak i katolik w Żmiącej, Toruń: Fundacja na rzecz Nauki Polskiej.

Metro. 2017. Atak na meczet w Warszawie. Policja szuka sprawców. Mogło być ich kilku, http://metrowarszawa.gazeta.pl/metrowarszawa/7,141637,22702148,osrodek-muzulmanski-na-ochocie-obrzucony-kamieniami-to-ksenofobiczny.html [9.05.2018].

Nalborczyk, Agata i Konrad Pędziwiatr. 2018. Between Old Traditions and New Diversities Islamic Religious Education in Poland, w: Jenny Berglund (ed.), European Perspectives on Islamic Education and Public Schooling, London: Equinox, s. 136-156.

Nowicka, Ewa (red.). 1990. Swoi i obcy, Warszawa: Uniwersytet Warszawski, Instytut Socjologii.

Nowicka, Ewa 1996. Wprowadzenie. Poznawanie swojskości i obcości, w: Ewa Nowicka i Jan Nawrocki (red.), Inny - obcy - wróg: Swoi i obcy w świadomości młodzieży szkolnej i studenckiej, Warszawa: Oficyna Naukowa, s. 7-28.

PCH24. 2018. Nadgorliwość policji utemperowana. Nie wszystko ze słowem „Arab” musi być mowa nienawiści, http://www.pch24.pl/nadgorliwosc-policji-utemperowana--niewszystko-ze-slowem-arab-musi-byc-mowa-nienawisci,38593,i.html?nom=1 [7.05.2018].

Pędziwiatr, Konrad. 2007. Od Islamu imigrantów do islamu obywateli:m uzutmanie w krajach Europy Zachodniej, Kraków: Nomos.

Pędziwiatr, Konrad. 2011. The Established and Newcomers in Islam in Poland or the InterGroup Relations within the Polish Muslim Community, w: Katarzyna Górak-Sosnowska (ed.), Muslims in Poland and Eastern Europe. Widening the European Discourse on Islam, Warszawa: Impuls, 169-182.

Pędziwiatr, Konrad. 2016. Islamophobia in Poland: National Report 2015, w: Farid Hafez i Enes Bayrakli (ed.), European Islamophobia Report 2015, Istanbul: SETA, s. 423-441.

Pędziwiatr, Konrad. 2017. Islamophobia in Poland: National Report 2016, w: Farid Hafez i Enes Bayrakli (ed.), European Islamophobia Report 2016, Istanbul: SETA, s. 411-443.

Prokuratura Krajowa. 2016. Wyciag ze sprawozdania dotyczacego spraw o przestepstwa popetnione z pobudek rasistowskich, antysemickich lub ksenofobicznych prowadzonych w I pótroczu 2016 r. w jednostkach organizacyjnych prokuratury, http://pk.gov.pl/plik/ 2016_10/24acf46588c7847967633b4cceaede99.pdf [9.05.2018]. 
„Rzeczpospolita”. 1994. Europejczycy dyskryminują muzułmanów. Wywiad z profesorem Januszem Daneckim, „Rzeczpospolita”, 15.12.1994.

Said, Edward W. 1978. Orientalism, London: Penguin.

Simmel, Georg. 2005. Socjologia, Warszawa: Wydawnictwo Naukowe PWN.

Skrodzka, Magdalena i Anna Stefaniak. 2017. Postawy wobec muzulmanów a przywiazanie do grupy własnej w Polsce, Warszawa: Centrum Badań nad Uprzedzeniami.

Stefaniak, Anna. 2015. Postrzeganie muzułmanów w Polsce: Raport z badania sondażowego, Warszawa: Centrum Badań nad Uprzedzeniami.

Stola, Dariusz. 2010. Kraj bez wyjścia? Migracje z Polski 1949-1989, Warszawa: Instytut Pamięci Narodowej.

Switat, Mustafa. 2017. Społeczność arabska w Polsce. Stara i nowa diaspora, Warszawa: Wydawnictwo Akademickie Dialog.

Szwed, Robert. 2003. Tożsamość a obcość kulturowa. Studium empiryczne na temat zwiąków pomiędzy tożsamościa społeczno - kulturowa a stosunkiem do obcych, Lublin: Wydawnictwo KUL.

Valentine, Gill. 2010. Prejudice: Rethinking Geographies of Oppression, „Social \& Cultural Geography", 11: 519-537.

Warmińska, Katarzyna. 1999. Tatarzy polscy: tożsamość religijna i etniczna, Kraków: TAiWPN Universitas.

Winiewski, Mikołaj, Karolina Hansen, Michał Bilewicz, Wiktor Soral, Aleksandra Świderska i Dominika Bulska. 2017. Mowa nienawiści, mowa pogardy: Raport z badania przemocy werbalnej wobec grup mniejszościowych, Warszawa: Fundacja im. Stefana Batorego.

Vertovec, Steven. 2007. Super-diversity and its implications, „Ethnic and Racial Studies”, 30, 6: 1024-1054.

Young, Iris. 1990. Justice and the Politics of Difference, Oxford: Princeton University Press.

\section{Lista wywiadów projektowych (porządek chronologiczny):}

1. Arkadiusz Miernik - AM, Birmingham 08.06.2016

2. Anonimowy przedstawiciel społeczności arabskiej 1-APSA1, Warszawa 20.09.2016

3. Ahmed Abdal - AA, Warszawa 20.09.2016

4. Anonimowy przedstawiciel społeczności muzułmańskiej-APSM, Gdańsk 14.10.2016

5. Olgierd Chazbijewicz - OC, Gdańsk 15.10.2016

6. Anonimowy przedstawiciel społeczności arabskiej 2 - APSA2, Katowice 09.03.2017

7. Agata Bouali - AB, Katowice 09.03.2017

8. Aneta Dziedzic - AD, Kraków 15.03.2017

9. Adham Abd El Aal - AEA, Warszawa 20.03.2017

10. Tomasz Miśkiewicz - TM, Białystok 12.01.2018

11. Artur Konopacki - AK, Białystok 12.01.2018

12. Karolina Radłowska - KR, Białystok 12.01.208

13. Ibrahim Khartouma - IK, Białystok 12.01.2018

14. Anonimowa przedstawicielka społeczności tatarskiej - APST, Białystok 13.01.2018

15. Halina Szahidewicz - HS, Białystok 13.01.2018 
16. Anonimowe małżeństwo tatarskie - AMT, Białystok 13.01.2018

17. Dżenneta Bogdanowicz - DB, Kruszyniany 15.01.2018

18. Bronisław Talkowski - BT, Kruszyniany 15.01.2018

19. Janusz Aleksandrowicz - JA, Białystok 17.01.2018

20. Rafał Berger - RB, Poznań 30.01.2018

21. Youssef Chadid - YC, Poznań 30.01.2018

22. Mohammad Saleh Messikh - MSM, Poznań 2.02.2018

23. Mariusz Turowski - MT, Wrocław 03.02.2018

24. Nezar Cherif - NC, Warszawa 17.02.2018

\section{TRANSFORMATIONS OF ATTITUDES TOWARDS ARABS IN THE POLISH SOCIETY FROM THE PERSPECTIVE OF MEMBERS OF THE ARAB AND MUSLIM COMMUNITIES}

In spite of numerous studies exploring the attitudes of Polish society towards followers of Islam including Arabs or studies showing how Polish media shapes the image of Muslims and Islam, there are hardly any analyses assessing how these attitudes and images are perceived by the minority group. The purpose of this text is to fill this gap and analyse the perception of transformation of attitudes in contemporary Polish society towards Arabs from the perspective of members of the Arab and Muslim communities. The article's analytical framework builds upon the conceptions problematizing a group sense of alienation and familiarity in the context of human mobility and immobility. In particular, the text shows the usefulness of the concept of otherness and strangeness developed by Ewa Nowicka in the late 1990s for the analysis of the transformation of attitudes towards Arabs and Muslims in Polish society in the last two decades.

Keywords: Muslims, Arabs, otherness, islamophobia, prejudices, Islam in Poland, strangeness

Zgłoszenie artykułu: 3.12.2019

Recenzje: 18.02.2020

Rewizja: 17.03.2020

Akceptacja: 17.03.2020

Publikacja on-line: 30.06 .2020 